\title{
BacMam Virus Transduced Cardiomyoblasts Can Be Used for Myocardial Transplantation Using AP-PEG-A Microcapsules: Molecular Cloning, Preparation, and In Vitro Analysis
}

\author{
Arghya Paul, ${ }^{1}$ Afshan Afsar Khan, ${ }^{1}$ Dominique Shum-Tim, ${ }^{2}$ and Satya Prakash ${ }^{1,3}$ \\ ${ }^{1}$ Biomedical Technology and Cell Therapy Research Laboratory, Department of Biomedical Engineering, Faculty of Medicine, \\ McGill University, 3775 University Street, Montreal, QC, Canada H3A 2B4 \\ ${ }^{2}$ Divisions of Cardiac Surgery and Surgical Research, The Montreal General Hospital, 1650 Cedar Avenue, Suite C9-169, \\ Montreal, QC, Canada H3G $1 A 4$ \\ ${ }^{3}$ Artificial Cells and Organs Research Centre, Faculty of Medicine, McGill University, Montreal, QC, Canada H3G 1 Y6 \\ Correspondence should be addressed to Satya Prakash, satya.prakash@mcgill.ca
}

Received 5 June 2010; Revised 14 September 2010; Accepted 10 November 2010

Academic Editor: Mohamed Boutjdir

Copyright ( 2010 Arghya Paul et al. This is an open access article distributed under the Creative Commons Attribution License, which permits unrestricted use, distribution, and reproduction in any medium, provided the original work is properly cited.

The potential of genetically modified cardiomyoblasts in treating damaged myocardium is well known. However, efficient delivery of these cells is of major concern during treatment. The limiting factors are the massive cell death that occurs soon after their intramyocardial transplantation into the beating heart. To address these problems, we generated recombinant baculoviruses (BacMam viruses) which efficiently transduced cardiomyoblast cells under optimized conditions. These genetically modified cells were then protected in a new polymeric microcapsule using poly-ethylene-glycol (PEG), alginate, and poly-L-lysine (PLL) polymers for efficient delivery. Results showed that microcapsules maintain cell viability and support cell proliferation for at least 30 days. The capsules exhibit strong immunoprotective potential and have high mechanical and osmotic stability with more than $70 \%$ intact capsules. The encased transduced cells showed a rapid transgene expression inside the capsule for at least 15 days. However, preclinical studies are needed to further explore its long-term functional benefits.

\section{Introduction}

The pathological findings in ischemic heart diseases are characterized by extensive cardiomyocyte apoptosis, necrosis, and replacement of myocardial tissue with noncontractile fibrous cells after myocardial infarction. Since mature cardiomyocytes are terminally differentiated cells, their natural replacement with fibrous tissue results in permanent loss of contractile myocardium and the formation of dilated congestive heart failure (CHF) [1]. Thus, embryonic or fetal origin cardiomyocytes become an important focus for cell therapy and cell-based gene therapy for the treatment of CHF [2]. However, the success of such experimental therapies relies mainly on their biosafety profiles, efficiencies of gene transfer for cell-based gene therapies, and suitable cell transplantation and supporting constructs. A lot of emphasis has been given to transplantation of neonatal cardiomyocytes, skeletal myoblasts, embryonic stem cells, marrow stromal cells, and genetically modified cells using biocompatible scaffolds to repair the damaged myocardial tissues [3-6]. The different types of scaffolds include natural matrices, such as collagen tubes, alginate hydrogels, and fibrin mesh [7-9]. 3-dimentional constructs using collagen and matrigel are also being proposed for efficient cell transplantation $[10,11]$. Another approach is to utilize thermosensitive polymers and electrospun nanofibre-based scaffolds to prepare biografts that can promote better cell proliferation as well as implant biodegradability $[6,12,13]$. Biodegradable polymers, such as polyurethane, carbonate, polyglycolic acid, polycaprolactone, and polylactic acid, are also being used for this purpose. A few of them have produced significant results in preclinical and clinical settings [14]. However, these modes of cell delivery have common drawbacks. Apart from high chances of getting immune rejection, a major portion of 
the transplanted cells get damaged soon after injection, and most of the remaining biologically active cells get washed out by the beating heart $[15,16]$.

Artificial cell microencapsulation, a concept in which biologically active materials are encapsulated in specialized ultrathin semipermeable polymer membranes, has been proposed here as means to address the above-mentioned problem [17-19]. These microcapsules provide a large surface area to volume ratio which promotes rapid diffusion of oxygen, nutrients, and waste metabolites. The semipermeable membrane of such microcapsules excludes antibodies, tryptic enzymes, and external materials but allows smaller molecules like peptides to enter and diffuse out of the cell $[17,20,21]$. Previous in vivo studies using standard APA microcapsules were not suitable for long-term transplantation, where it was often followed by encapsulated cell necrosis and fibrotic tissue growth around the membrane surface [22-24].

In this study, recombinant baculoviruses carrying Monster Green Fluorescent Protein gene under the control of mammalian CMV promoter were generated (Bac-MGFP) for genetically modifying the cardiomyocytes before encapsulation. Detailed studies to optimize the transduction conditions with minimum cytotoxicity towards the cardiomyocytes, including the effects of epigenetic factors [25], were done. These modified baculoviruses, known as BacMam viruses for carrying mammalian expression cassettes, are considered to be biologically safe as they cannot replicate or express their own genes in mammalian cells $[26,27]$. The genetically modified cells were then encapsulated in AP-PEG-A microcapsules and evaluated for their potential in giving immunogenic and mechanical protections to the entrapped embryonic cardiomyocytes against the harsh external environment, which is particularly important for cell transplantation to the beating heart.

\section{Materials and Methods}

2.1. Insect Cell Cultures. Sf9 insect cells (Invitrogen Life Technologies, Carlsbad, CA) were maintained at $27^{\circ} \mathrm{C}$ in SF900 III serum-free medium in stationary flasks. The cells were maintained in exponential growth phase and subcultured twice per week. For larger volumes, cells were grown in shaker flasks (Erlenmeyer, Corning) while being agitated with $120 \mathrm{rpm}$ at $27^{\circ} \mathrm{C}$ incubator shaker $[28,29]$.

2.2. Construction of BacMam Vector. The pVL1392 baculoviral transfer vector and phMGFP vector carrying the Monster Green Fluorescent Protein (MGFP) were obtained from BD Biosciences and Promega, respectively. The phMGFP and pVL1392 vectors were digested with BglII and XbaI restriction enzymes. The cutout $\mathrm{P}_{\mathrm{CMV} \text {-hMGFP }}$ gene from phMGFP and linearized pVL1392 vector were ligated to form

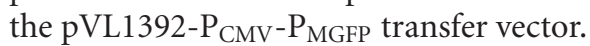

2.3. Cotransfection of Insect Cells and Generation of the BacMGFP Viral Stock. To generate the recombinant MGFP baculoviruses, $1 \times 10^{6} \mathrm{Sf9}$ cells were seeded in 6-well plates, and transfection procedure was followed using previously described method [30]. Briefly, a transfection mixture, comprising of $1 \mu \mathrm{g}$ of the constructed BacMam transfer vector, linearized baculovirus DNA (BD Baculogold), and $6 \mu \mathrm{L}$ of the Cellfectin transfection reagent diluted in $200 \mu \mathrm{L}$ SF900 III media (Invitrogen Life Technologies, Carlsbad, CA), was prepared. The mixture was incubated for 45 minutes at room temperature and then cotransfected to the seeded cells. After $5 \mathrm{hr}$ of incubation at $27^{\circ} \mathrm{C}$, the transfection media was replaced with Sf900III media, and the cells were further incubated at $27^{\circ} \mathrm{C} .96 \mathrm{~h}$ after transfection, the cell cultures were collected, centrifuged at $1000 \mathrm{xg}$ for $10 \mathrm{~min}$, and then the supernatant containing the baculovirus was filtered through a $0.22-\mu \mathrm{m}$ membrane and stored at $4^{\circ} \mathrm{C}$ (P0 Virus Stock). The viral stock, measured in terms of plaque forming unit (pfu), was amplified by scaleup in shaker flask cultures $[28,29]$. Briefly, Sf9 cells were grown till mid-exponential phase and diluted to $2 \times 10^{6}$ cells $/ \mathrm{mL}$ with SF900III medium. The cultures were infected with P0 virus stock at an MOI (pfu/cell) of 0.1. During the infection process, the total and viable cell densities were measured using trypan blue in hemocytometer. The infected cell culture containing the amplified recombinant baculoviruses was harvested (P1 stock) by centrifugation when cell viability was between 75 and $80 \%$. Baculovirus with the CMV promoter and no MGFP gene (Bac-null) was also generated in a similar way.

\subsection{Quantification of Baculoviral Titre by Immunological} Assay. The viral titre, measured as plaque forming unit $(\mathrm{pfu}) / \mathrm{ml}$ was determined using Novagen's Baculovirus Fast Plax Titer Kit according to the manufacturer's protocol. The Sf9 cells were plated in 6-well plate with $1 \times 10^{6}$ cells per well. After serial dilution of the viral stocks in Sf900III media, the $200 \mu \mathrm{L}$ aliquots were added to each well. At the end of $1 \mathrm{hr}$ incubation, $2 \mathrm{~mL}$ media was added to each well followed by $30 \mathrm{~h}$ incubation at $27^{\circ} \mathrm{C}$ in a sealed humid chamber. The cells were then washed twice with PBS (Invitrogen) and fixed in 3.7\% formaldehyde solution. After blocking the cells with $1 \%$ gelatin, Fast Plax monoclonal primary antibody (diluted $1: 10,000$ ), specific to the baculovirus glycoprotein 64, was added to the cells. After $1 \mathrm{~h}$ incubation, the cells were washed in wash buffer ( $10 \mathrm{mM}$ Tris- $\mathrm{HCl} \mathrm{pH}$ 8.0, $0.15 \mathrm{M}$ $\mathrm{NaCl}, 0.1 \%$ Tween-20) and incubated for another $1 \mathrm{~h}$ with $\beta$ galactosidase- conjugated goat antimouse antibody (diluted $1: 100)$. This was followed by X-Gal staining which detects the single infected cells and foci of infected cells by their dark blue color.

2.5. Culture and Transduction of Cardiomyocytes. The H9c2 myogenic cell line derived from embryonic rat heart ventricles was obtained from American Tissue Culture Collection (CRL 1446) and cultured in DMEM supplemented with $10 \%$ FBS. The cells were routinely maintained as stationary cultures in T-75 flasks, incubated at $37^{\circ} \mathrm{C}$ in a controlled environment with $5 \% \mathrm{CO}_{2}$. To check the GFP fluorescein expression, $2 \times 10^{4}$ cells/well were seeded in 96-well plates and transduced for $6 \mathrm{~h}$ with baculoviruses at varied MOI resuspended in $200 \mu \mathrm{L}$ PBS at $27^{\circ} \mathrm{C}$. The viral solution was 


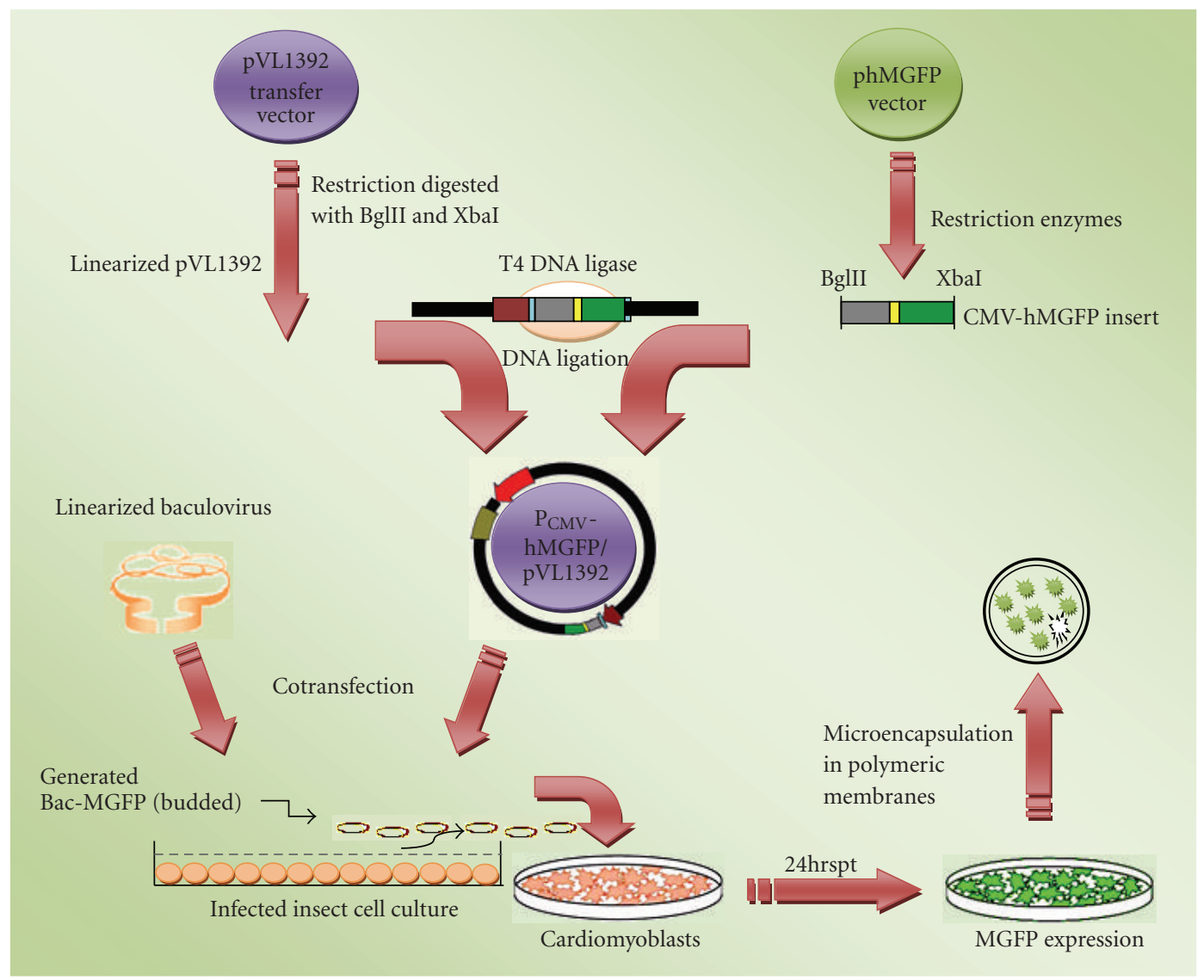

FIGURE 1: Schematic representation of molecular cloning strategy for generation of recombinant BacMam virus and microencapsulation of transduced cells. The reporter gene hMGFP was excised along with the CMV promoter from phMGFP vector using BglII and XbaI restriction enzymes and inserted in the MCS of the baculovirus transfer vector pVL1392 to construct the $\mathrm{P}_{\mathrm{CMV}-\mathrm{hMGFP}} / \mathrm{pVL1392}$ plasmid. The BacMam viruses generated by cotransfection were transduced to the cardiomyocytes. This was followed by microencapsulation and tracking the MGFP expression of the transduced cells.

replaced with $200 \mu \mathrm{L}$ cell medium supplemented with $10 \mathrm{mM}$ $\mathrm{NaBu}$ or only cell medium. 24 hour posttransduction (hpt), fluorescein readings $(485 \mathrm{~nm} / 535 \mathrm{~nm})$ of the individual wells were taken with the plate reader (Victor3 Multilabel Counter from Perkin Elmer).

2.6. PCR Analysis. The cardiomyocyte cells were seeded in 6 -well plates at $5 \times 10^{5}$ cells/well using serum-supplemented DMEM media and were allowed to attach overnight in the incubator. For transduction, the cell medium was replaced by $500 \mu \mathrm{L}$ of PBS containing either Bac-MGFP virus or no virus. After $6 \mathrm{~h}$ of viral incubation at $27^{\circ} \mathrm{C}$, the viral solution was removed, and the cells were washed twice in PBS and replenished with $2 \mathrm{~mL}$ of fresh media treated with or without $10 \mathrm{mM} \mathrm{NaBu}$ for further culture in the $37^{\circ} \mathrm{C}$ incubator. For detection of MGFP gene in the cells $24 \mathrm{hpt}$, total DNA was extracted from $1 \times 10^{6}$ transduced and mock-transduced cells cultured in 6 well plates using the DNA extraction kit (from Qiagen), according to the manufacturer's instructions. The obtained DNA was then PCR amplified using Taq DNA Polymerase (Invitrogen), following the conditions given in Table 1. Amplifications were carried out for 25 cycles at $94^{\circ} \mathrm{C}$ for $35 \mathrm{sec}$ (denaturation), $55^{\circ} \mathrm{C}$ for $35 \mathrm{sec}$ (annealing) and $72^{\circ} \mathrm{C}$ for $25 \mathrm{sec}$ (extension).

\subsection{Cytotoxicity Assay Using Factorial Matrix Design Exper-} iments. The cytotoxicity for the virus and sodium butyrate $(\mathrm{NaBu})$ as the histone deacetylase inhibitor was evaluated using the Cell Titer 96 Aqueous Nonradioactive Cell Proliferation MTS Assay (Promega). MTS is chemically reduced by viable cells into formazan, which is soluble in tissue culture medium. The dehydrogenase enzyme activity found in the metabolically active cells is measured in terms of light absorbance values in this assay. The measurement of the absorbance of the formazan was carried out using the plate reader (Victor3 Multilabel Counter from Perkin Elmer) at $490 \mathrm{~nm}$. Since the production of formazan is directly related to the number of living cells, the intensity of the produced color is an indicator of the viable cells. The factorial design experiments were done to check the variation in toxicity level of $\mathrm{H} 9 \mathrm{c} 2$ cells with respect to $\mathrm{MOI}$ and $\mathrm{NaBu}$ concentration using Design-Expert software as used earlier [28]. For this, the cardiomyocyte cells were seeded in a 96 well plate with $2 \times 10^{4}$ cells per well using serum-supplemented DMEM. 
TABle 1: Primer sequences used in PCR.

\begin{tabular}{|c|c|c|c|c|}
\hline Gene & Forward sequences & Reverse sequences & $\begin{array}{l}\text { Annealing } \\
\text { temp } \\
\text { (cycles) }\end{array}$ & $\begin{array}{l}\text { Product } \\
\text { size } \\
\text { (bp) }\end{array}$ \\
\hline MGFP & 5' GATGCAGCGCAAGACCCTAAAG3' & 5' GGTCTTGAAGTCGCAGCGGTAG3' & $55^{\circ} \mathrm{C}(25)$ & 133 \\
\hline GAPDH & 5' TCAAGGGCATCCTGGGCTAC3' & 5' AAGTGGTCGTTGAGGGCAATG3' & $55^{\circ} \mathrm{C}(25)$ & 112 \\
\hline
\end{tabular}

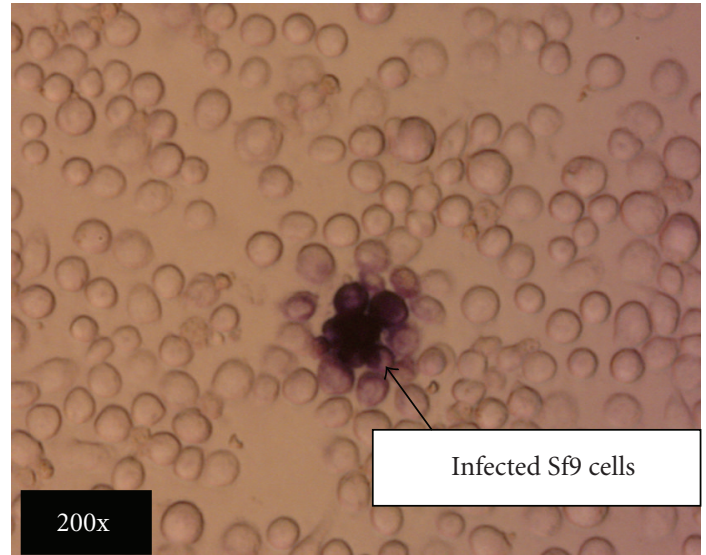

FIGURE 2: Immunological staining of baculovirus-infected Sf9 cells using FastPlax Titre kit. The Sf9 cells were infected with diluted baculoviral stock, and after $24 \mathrm{hrs}$ the cells were fixed, and gp64 protein was detected on the cell surfaces by using monoclonal antigp64 antibody and $\beta$-galactosidase-conjugated secondary antibody.

The Bac-null was added to the seeded cells with varied range of MOI (500 to 2000) in presence of DMEM + 10\% FBS. This was followed by addition of $\mathrm{NaBu}$ (ranging from $0 \mathrm{mM}$ to $20 \mathrm{mM}$ ) to the infection media after an incubation time of $6 \mathrm{~h}$. After $48 \mathrm{~h}$ the cytotoxicity test was done by MTS assay as per the manufacturer's instructions mentioned in earlier work [31]. The experiments were performed in triplicates.

2.8. Encapsulation of Cardiomyocytes in Polymeric Microcapsules. The H9c2 cells were encapsulated in alginate microcapsules using our previously established procedures $[23,32,33]$. Transduced or nontransduced H9c2 cells were suspended in $1.5 \%$ sodium alginate (Sigma Chemicals, St. Louis, MO, USA) at a cell concentration of $2 \times 10^{6}$ cells $/ \mathrm{mL}$. The suspension was extruded through an encapsulator (Inotech) fitted with a $300 \mu \mathrm{m}$ nozzle at a voltage of $0.577 \mathrm{kV}$ and frequency of $710 \mathrm{~Hz}$. The gelation process took place in a $0.1 \mathrm{M} \mathrm{CaCl}_{2}$ solution for $15 \mathrm{~min}$. The newly generated alginate microcapsules were immersed in $0.05 \%$ (w/v) poly-l-lysine (PLL; Sigma Chemicals) solution for $10 \mathrm{~min}$. The PLL-coated alginate capsules were immersed in $0.5 \%$ solution of PEG dissolved in $0.45 \% \mathrm{NaCl}$ for $15 \mathrm{~min}$. The capsules were washed twice with physiological solution before every coating and then subjected to a final coating of $0.1 \%$ alginate. The washed capsules were then transferred to stationary cell culture flasks resuspended in DMEM medium supplemented with 10\% FBS and antibiotic antimycotic solution (Sigma) for further culture in $37^{\circ} \mathrm{C}$ incubator with
$5 \% \mathrm{CO}_{2}$. Microcapsules were replenished with fresh media every alternate day.

2.9. Tracking the Cell Growth and Viability of Microencapsulated Cells. Growth of the cells within microcapsules was assessed using polyanionic calcein AM dye (Biotium Inc., Hayward, USA). Using the dye, the live cells were detected by the intracellular esterase-mediated conversion of the nonfluorescent cell-permeant calcein AM to the fluorescent green calcein [34]. 50 microcapsules, encapsulating the cells, were first washed with PBS and incubated with $200 \mu \mathrm{L}$ of fresh PBS containing $2 \mu \mathrm{M}$ calcein AM. After $1 \mathrm{~h}$, the wells were checked under the fluorescence microscope, and fluorescein measurements (excitation $485 \mathrm{~nm}$, emission $535 \mathrm{~nm}$ ) of the wells were taken with a plate reader (Perkin Elmer). The background fluorescence detected in the wells with microcapsules having no cells was taken as the negative control.

To assess the percentage of cells viable within the microcapsules, calcein AM and ethidium homopolymer EthD-III dyes (Biotium Inc., Hayward, USA) were used. The dyes help to differentiate the viable and dead cells within the microcapsules. The dead cells were detected by the bright red fluorescence emitted by EthD-III dye on binding with the nucleic acids, which enters only dead cells through their damaged membranes. The microcapsules were first washed twice with PBS, $10 \mathrm{~min}$ each, and resuspended in fresh PBS buffer. $2 \mu \mathrm{M}$ calcein AM and $4 \mu \mathrm{M}$ EthD-III were then added to the microcapsules and incubated for $1 \mathrm{~h}$ before checking under the fluorescence microscope. The numbers of microencapsulated fluorescent green cells were counted against fluorescent red cells in three different experiments, and the average percentage viability of intracapsular cells was calculated.

2.10. Stability Test of the Microcapsules. The mechanical stability of the AP-PEG-A microcapsules was determined by applying a joint osmotic pressure and rotational stress test [35]. The osmotic pressure test was performed by directly transferring 500 microcapsules, encapsulating known amount of cells, previously stored in $0.85 \%$ saline solution to $5 \mathrm{~mL}$ deionized water in a $25 \mathrm{~mL}$ volumetric flask. To implement the rotational stress, the capsules suspended in hypotonic solution (deionized water) were then shaken in a horizontal shaker (Environ) at a speed of $150 \mathrm{rpm}$ at $37^{\circ} \mathrm{C}$ for $120 \mathrm{~min}$. In order to assess the ability of the microcapsules to withstand these stresses, photomicrographs of the microcapsules were taken at different time points. Samples were also collected from time to time for counting 


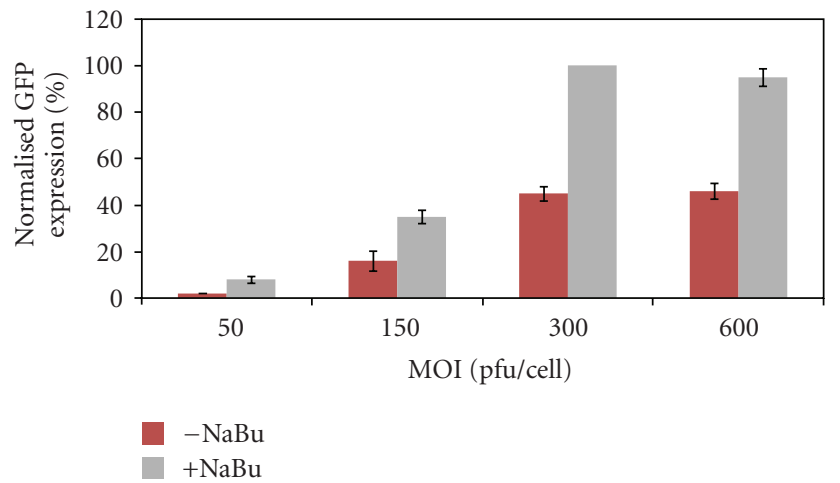

(a)
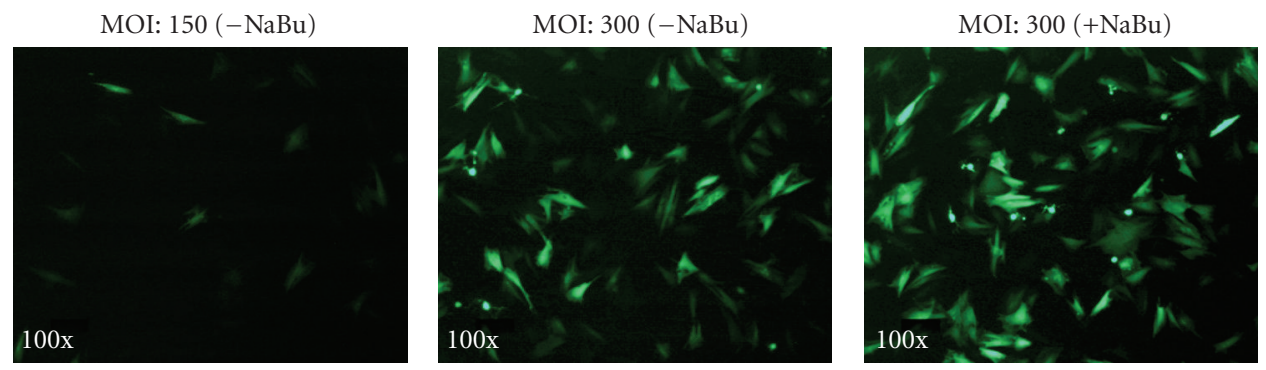

(b)

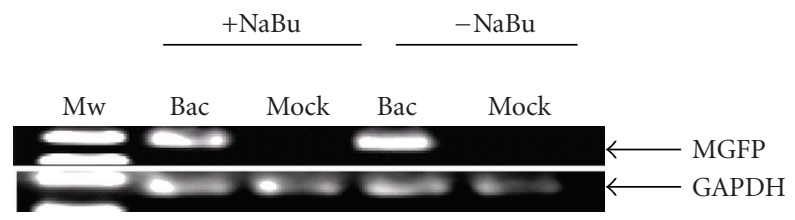

(c)

FIgUre 3: Effect of $\mathrm{NaBu}$ and viral dose in $\mathrm{H} 9 \mathrm{c} 2$ cells' transgene expression. Cells were transduced with $\mathrm{Bac}-\mathrm{MGFP}$ for $6 \mathrm{~h}$ in $\mathrm{PBS}$ at $27^{\circ} \mathrm{C}$ with and without $10 \mathrm{mM} \mathrm{NaBu}$ treatment at different viral doses. Quantification (fluorescein expression) of fluorescent in H9c2 cells (a) were made with relation to viral dosage $24 \mathrm{hpt}$. The average fluorescein-expressed (excitation $485 \mathrm{~nm}$, emission $535 \mathrm{~nm}$ ) values were normalized to that of the cells having $6 \mathrm{~h}$ of viral incubation in presence of PBS (taken as 100\%) and are represented as normalized mean expression in percentage value. The data represent mean of three different readings. (b) Fluorescence images of transduced cells in absence and presence of $\mathrm{NaBu}$ are shown $24 \mathrm{hpt}$. (c) Detection of MGFP plasmid delivery in H9c2 cells $24 \mathrm{hpt}$ in presence or absence of NaBu by standard PCR analysis. Cells were given equal viral dose with same viral incubation time. Nontransduced cells were taken as the control (mock) for the transduction procedure. The DNA was extracted from the transduced cells $24 \mathrm{~h}$ after transduction, and PCR analysis was done using primers that amplify the delivered MGFP gene. Amplification of housekeeping GAPDH gene serves as an internal control for the efficiency of polymerase reaction. Molecular weight $(\mathrm{Mw})$ markers are low range DNA ladder. The similar band intensities in the agarose gel indicates that there was equal viral transduction in both $+\mathrm{NaBu}$ and $-\mathrm{NaBu}$ groups, although the corresponding protein expression was higher in $+\mathrm{NaBu}$ (as shown in (a) and (b)). This proves that $\mathrm{NaBu}$ does not interfere in viral transduction procedure but significantly improves the transgene expression.

the number of free cells, using hemocytometer, which were released from the ruptured capsules. Thus, the percentage of cells that remained entrapped inside the intact microcapsules with time was calculated.

2.11. Immunoprotective Behavior of the Microcapsules against Lymphocytes. In order to investigate the potential of the membrane to provide immunoprotection to the encapsulated cells, 50 AP-PEG-A capsules encapsulating the cells were cocultured in $1 \mathrm{~mL}$ of media containing $5 \times 10^{4}$ lymphocytes per well of a 24 -well plate [23]. As the lymphocytes secrete cytokines, the viability of the encapsulated cardiomyocyte cells will depend on the immunoisolation properties of the capsular membrane. Capsules were withdrawn periodically to test the viability of the encapsulated cardiomyocytes by calcein AM and EthD-III dyes using the procedure mentioned above.

2.12. Microencapsulation of Baculovirus-Transduced Cells. $\mathrm{H} 9 \mathrm{c} 2$ cells were transduced with Bac-MGFP at an MOI of 300 for $6 \mathrm{~h}$ at $27^{\circ} \mathrm{C}$. They were then encapsulated at a concentration of $2 \times 10^{6}$ cells per $\mathrm{mL}$ of alginate that followed further coatings to prepare the AP-PEG-A microcapsules. The encapsulated cells were then cultured in stationary 


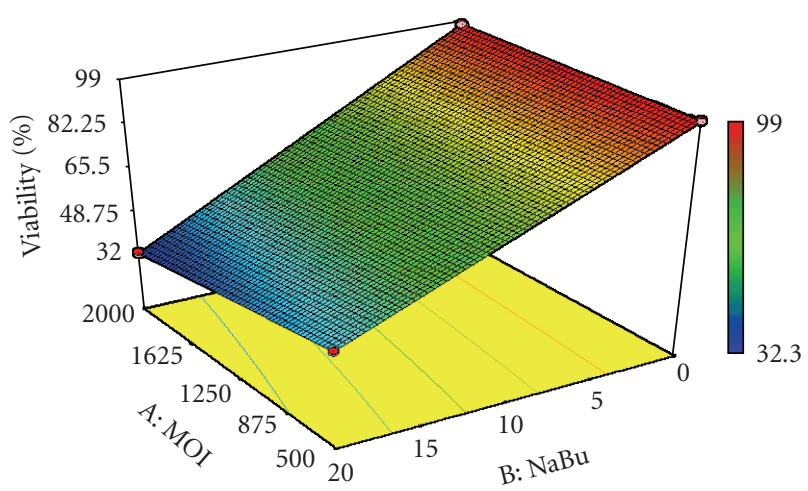

Design-Expert software

Viability \%

$X 1=\mathrm{A}: \mathrm{MOI}$

$X 2=\mathrm{B}: \mathrm{NaBu}$

Figure 4: The effect of MOI and $\mathrm{NaBu}$ concentration on cell viability. The graph was generated using ANOVA analysis software (Stat-Ease Design Expert). Three-dimensional surface view of numerical optimization graph shows the cell viability.

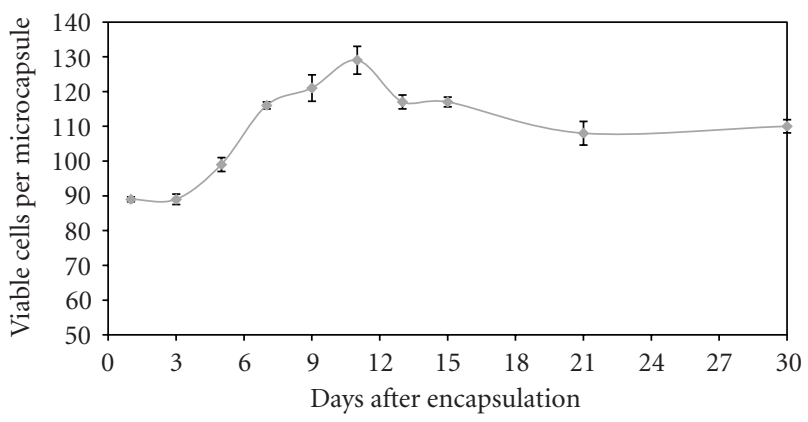

Figure 5: Cell survival and growth kinetics of the Bac-null transduced cells encapsulated in AP-PEG-A microcapsules. For the encapsulation $2 \times 10^{6}$ cells $/ \mathrm{ml}$ of alginate were used and maintained in DMEM $+10 \%$ FBS at $37^{\circ} \mathrm{C}$ and were incubated for 30 days. Medium was replaced at alternate days. Experimental samples were treated with calcein AM for $1 \mathrm{~h}$, and they were measured using fluorescence plate reading at excitation $485 \mathrm{~nm}$, emission $535 \mathrm{~nm}$.

flasks in 10\% DMEM medium supplemented with FBS and antibiotics. At different time intervals, 50 microcapsules containing the transduced cells were collected, washed with PBS, and resuspended in $200 \mu \mathrm{L}$ of fresh PBS in 96-well plates. The wells were checked under fluorescence microscope, and fluorescein measurements (excitation $485 \mathrm{~nm}$, emission $535 \mathrm{~nm}$ ) of the wells were taken with a plate reader (Perkin Elmer). The background fluorescence as detected in the wells with microcapsules with no cells was taken as the negative control.

\section{Results and Discussion}

3.1. Generation of Recombinant Bac-MGFP Viruses from Insect Cell Culture. The recombinant baculovirus was constructed as depicted in Figure 1 using the BacMam expression system. This is a powerful tool for different gene therapy applications as it combines the advantages of highly efficient transient transgene expression, ease in generation, and a wide cell tropism [27]. Although the transient expression can be termed as a kind of backlog to the system, it is a much desirable feature, thinking from biosafety perspectives. The transient expression is attributed to the lack of natural mechanism of baculovirus to integrate with the host genome which, on the other hand, is an inherent nature of the commonly used mammalian viruses such as adenovirus, adeno-associated, and lentivirus [28, 30]. Where these mammalian viral vectors have the probability to randomly integrate into the host's crucial genomic regions, thereby resulting in unexpected tumorigenesis, baculovirus holds a much better safety profile. Many safety issues are currently under consideration with present mammalian virus-based gene therapy trial [29]. At this point in time, insect cell specific baculovirus can play an important role as a potential biologically safe gene delivery vehicle.

The titre of the virus stock obtained in our studies was $2.4 \times 10^{9} \mathrm{pfu} / \mathrm{mL}$ as determined by the immunological assay method originally developed by Kitts and Green [36]. The advantage of this method is that it quantifies the infectious particles within 20-48 h using Sf9 cells, whereas other methods, like the end-point dilution method and plaque assay method, take 7 to 10 days to quantify [26]. Quantification techniques for baculovirus titration also includes usage of viable cell size [37], q-PCR [38], and fluorescence labeling [39]. The current method uses the immunological techniques to detect the baculoviral external glycoprotein gp64 on the infected Sf9 cell surface. The dark blue color plaques in Figure 2 show the insect cells infected with baculovirus $24 \mathrm{~h}$ after infection, where the baculoviral gp64 was detected by using monoclonal antibody against it.

3.2. Modulation of Transgene Expression by Regulating the Transduction Parameters: Viral Dosage and Treatment with Epigenetic Factor. In order to optimize the in vitro transduction efficiency of baculovirus in rat cardiomyocytes various critical parameters were considered. To investigate, $2 \times$ $10^{4}$ H9c2 cardiomyocytes, were seeded in 96-well plates and transduced with $200 \mu \mathrm{L}$ PBS containing Bac-MGFP of various doses under transduction temperature of $27^{\circ} \mathrm{C}$. After $6 \mathrm{~h}$ of transduction, the cells were washed twice with PBS and replenished with fresh medium containing $10 \mathrm{mM}$ sodium butyrate or only medium. The viral dose plays an important role in transduction of $\mathrm{H} 9 \mathrm{c} 2$ cells which is evident for the data in Figure 3(a), where a gradual increase of viral dose from MOI of 50 to 300 shows a corresponding increase in transgene expression while a higher MOI of 600 did not show further increase of expression. Thus, MOI of 300 was optimal for $\mathrm{H} 9 \mathrm{c} 2$ cells.

To examine whether epigenetic modifications can regulate gene expression $10 \mathrm{mM}$ sodium butyrate was added to the replaced DMEM media after transduction and incubated in the incubator for $24 \mathrm{~h}$. Figure 3 (a) shows that the histone deacetylase inhibitor has a positive effect on gene expression of the cells transduced with equal MOI. It demonstrates that 


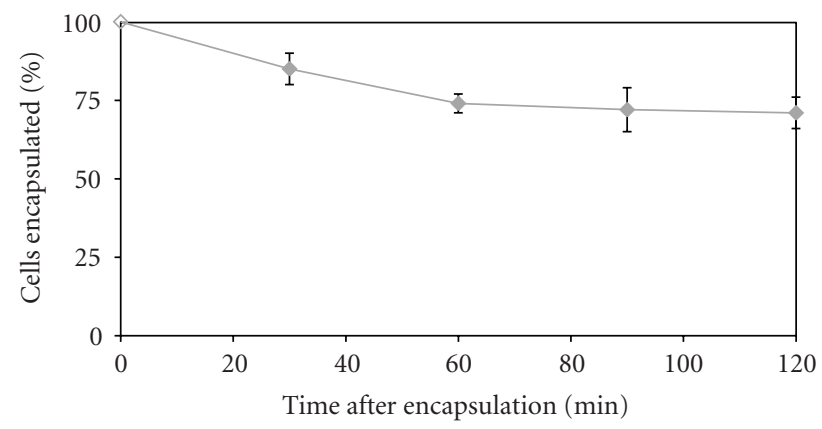

(a)

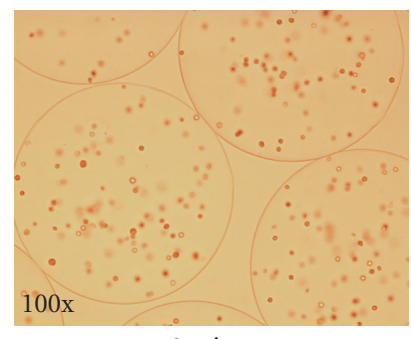

$0 \mathrm{~min}$

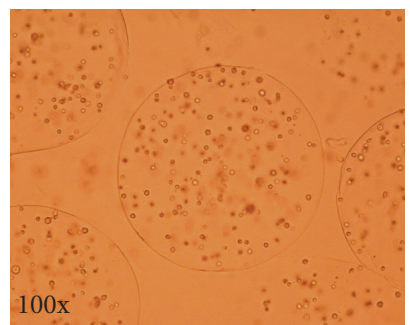

$60 \mathrm{~min}$

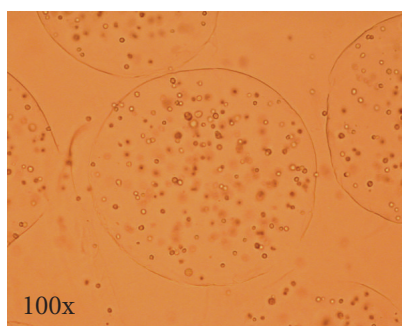

$120 \mathrm{~min}$

(b)

FIGURE 6: Mechanical and osmotic stability of the AP-PEG-A membrane. The microcapsules prepared by microencapsulating of $2 \times$ $10^{6}$ cells/mL of alginate were subjected to osmotic pressure and rotational stress by rotating them in a hypotonic solution at $150 \mathrm{rpm}$ in a horizontal shaker for $120 \mathrm{~min}$. Samples were collected from time to time; number of free cells were counted in hemocytometer to know the percentage of cells still encapsulated inside the intact microcapsules (a). The data represent the mean of three independent experiments, and error bars represent standard error of the mean. Representative bright field images of the microcapsules encapsulating H9c2 cells under 100x magnifications (b).

the H9c2 cardiomyocytes' GFP expression was almost double in $\mathrm{NaBu}$-treated cells with respect to nontreated cells, and this result was consistent under different viral doses. The fluorescence image of Figure 3(b) represents an example of the positive effects of viral dosage and $\mathrm{NaBu}$ on $\mathrm{H} 9 \mathrm{c} 2$ cell expression.

PCR analysis was done on the transduced cells to show that, although there was a marked difference in the amount of transgene protein expression level between the $\mathrm{NaBu}$ treated and nontreated cells, they had same amount of MGFP transgene DNA present within them due to equal viral dosage. Thus, Figure 3(c) reconfirmed that it was only the treatment of $\mathrm{NaBu}$ that upregulated the transcription of MGFP within the cells by inducing the acetylation of histones. This, in other words, illustrates that higher levels of expression are achievable in recombinant baculovirustransduced cells by the application of $\mathrm{NaBu}$, which results in an increase in the expression by blocking deacetylation of histone proteins bound to DNA.

But unlike the other viruses, baculovirus generally shows a lower transduction level in vivo because of serum inactivation due to complement sensitivity [40]. Blocking the C component 5 of the complement system using antibody or cobra venom factor enhances the transduction level significantly. Recent animal studies have also revealed that simple coating of viral particles with polycationic polyethylenimine polymers can produce serum-resistant baculoviruses $[41,42]$. Here, through ex vivo transduction of the cardiomyocytes, we are averting the possibility of inefficient gene delivery through in vivo viral inactivation. Moreover, transplanting genetically modified cells makes the delivery system biologically much safer in comparison to direct viral delivery in vivo. A wide range of mammalian viruses, such as lentivirus, adenovirus, and adeno-associated virus, have shown to efficiently transfer transgene in vivo to cardiac cells for myocardial therapy [43-45]. An illustrative work by Grassi et al. showed that both adenovirus and baculovirus transduce human cardiomyocytes equally and efficiently [25]. Using cellular DNA replication analysis, the group also showed that adenoviral vector has a major and more extended harmful effect on cardiovascular cells than insect cell-originated recombinant baculoviruses. Another work by Pieroni et al. showed that baculovirus expressing vesicular stomatitis virus glycoprotein in its envelope can transduce the mouse myoblasts and myotubes more efficiently than normal baculovirus which lacks the glycoprotein [46]. The group also performed in vivo studies which showed that the modified baculovirus can efficiently transfer gene in mouse skeletal muscle, and the persistence of this transgene expression depends on the mouse strain.

3.3. Detection of Cytotoxic Effects of Baculovirus and $\mathrm{NaBu}$ on Cardiomyoblasts. In order to evaluate the individual and combinatorial toxic effects of baculovirus and $\mathrm{NaBu}$ on 


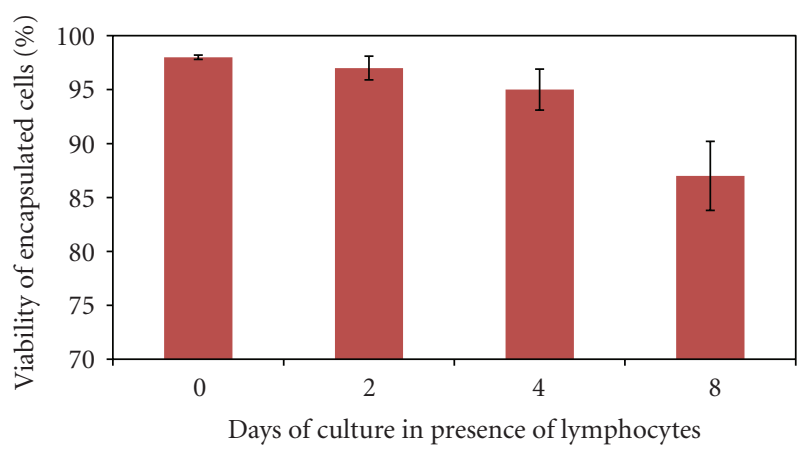

(a)

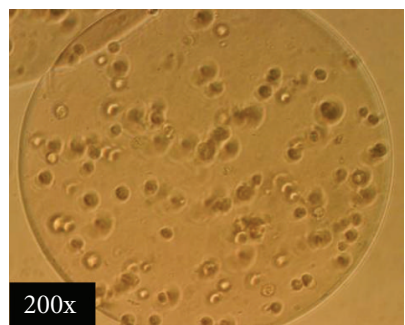

Bright field

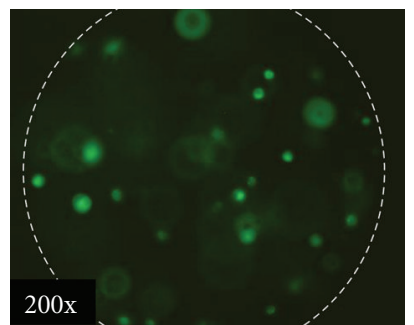

Calcein staining

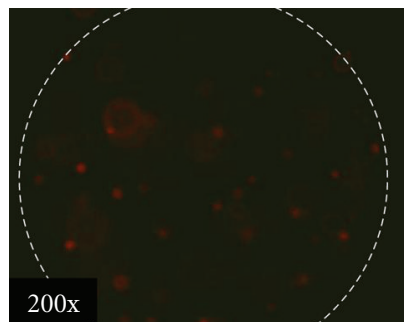

EthD-III staining

(b)

FIGURE 7: Immunoprotective potential of the AP-PEG-A membrane. Microcapsules were prepared by microencapsulating $2 \times 10^{6}$ Bac-null transduced $\mathrm{H} 9 \mathrm{c} 2$ cells $/ \mathrm{ml}$ of alginate and cultured in DMEM $+10 \% \mathrm{FBS}$ in $37^{\circ} \mathrm{C}$ incubator for 8 days in presence of lymphocytes. Medium was replaced on every alternate day. Samples were collected at regular intervals and subjected to viability test. Viability tests were done by using the calcein AM (showing viable cells in green) and ethidium homopolymer (showing dead cells in red) dye. The data represent the mean of three independent studies, and error bars represent standard error of the mean (a). Representative bright field and fluorescent images of a capsule encapsulating the cells under 200x magnifications in a fluorescence microscope (b). The white-dotted circles show the peripheral surface of the capsules.

TABLE 2: Factors checked in toxicity test for $\mathrm{H} 9 \mathrm{c} 2$ and their concentrations in factorial design experiment. The cells were treated with the components for $48 \mathrm{hrs}$ before performing the toxicity assay.

\begin{tabular}{lcccc}
\hline \multirow{2}{*}{ Factors } & \multirow{2}{*}{ Name } & \multicolumn{3}{c}{ Fixed levels used } \\
& & Low & Mean & High \\
\hline$A$ & $\mathrm{MOI}(\mathrm{pfu} / \mathrm{cell})$ & 500 & 1250 & 2000 \\
$B$ & $\mathrm{NaBu}(\mathrm{mM})$ & 0 & 10 & 20 \\
\hline
\end{tabular}

the cells, factorial matrix design experiments were performed and optimized for ideal viral dose and $\mathrm{NaBu}$ concentration with respect to cell toxicity percentage as measured by MTS assay. The cytotoxic factors and the range of study are mentioned in Table 2. The graph generated by the DesignExpert software in Figure 5 demonstrates that there is no significant cytotoxic effect (viability $\sim 99 \%$ ) of high Bacnull viral dose (MOI: 2000) on the cells even when exposed for $48 \mathrm{~h}$, in absence of $\mathrm{NaBu}$. While $\mathrm{NaBu}$ enhances gene expression, it also has a toxic effect on the cells as is evident by the low viability percentage of the cells when exposed to a high concentration of $\mathrm{NaBu}$ for $48 \mathrm{~h}$. Thus, performing more experiments based on the factorial matrix design experiment, we optimized that a low concentration of $10 \mathrm{mM} \mathrm{NaBu}$ with a lesser exposure time of $24 \mathrm{~h}$ is optimum to achieve maximum expression level with minimum cytotoxic effects.
3.4. Examining the Biocompatibiity of the PEG-Integrated Microcapsules by Monitoring Cell Growth. To test if the PEGincorporated capsules supports cell survival and proliferation, Bac-null transduced $\mathrm{H} 9 \mathrm{c} 2$ cells were encapsulated in AP-PEG-A microcapsules with the same cell density. The starting average cell population per capsule was around 90 cells. Using calcein staining, the total number of viable cells per capsule was measured and calculated through the fluorescence plate reader at different time intervals. For this, a standard curve of fluorescein absorbance with predetermined number of calcein-stained encapsulated cells was used as the reference. The anchorage-dependant cells were able to survive inside both types of alginate capsules. The graph in Figure 6 shows an increase in cell number from day 6 to day 12. This shows that the cells can proliferate inside the PEG-incorporated microcapsules. The graph also showed that after day 12 there was a drop of viable cell count in the capsules, but it maintained an average viable cell count above 100 per capsule for at least 30 days. Thus, it is evident that capsules have a good biocompatibility profile with $\mathrm{H} 9 \mathrm{c} 2$ cells and that there is no adverse effect on the cell survival and growth kinetics due to incorporating PEG layer to the capsules. The capsular shape also solves the limitations associated with other delivery systems, such as a thick scaffold system, where with increasing cellular density there arises a major difficulty in transfer of oxygen and 


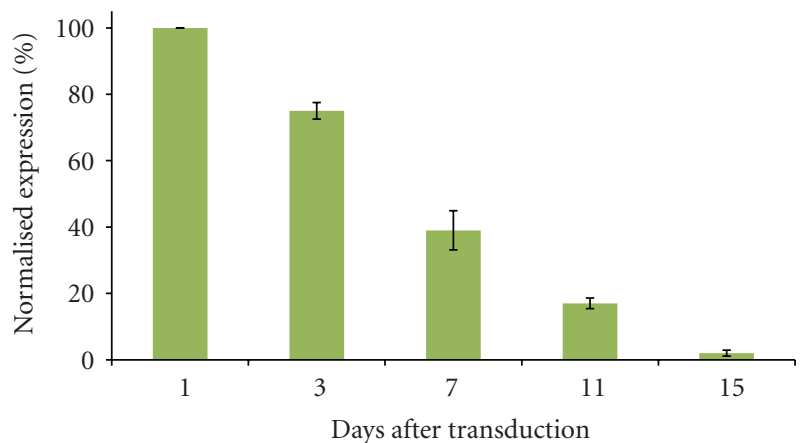

(a)

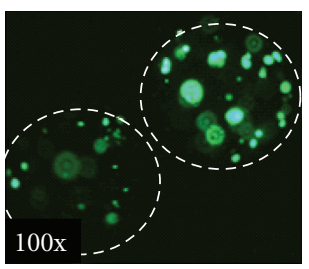

Day 1

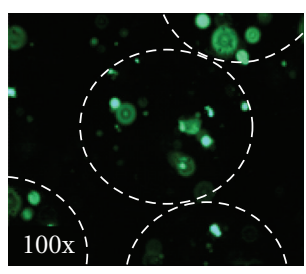

Day 7

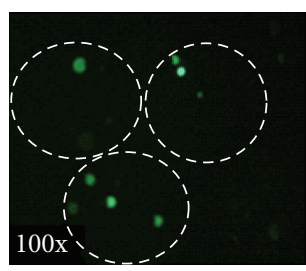

Day 11

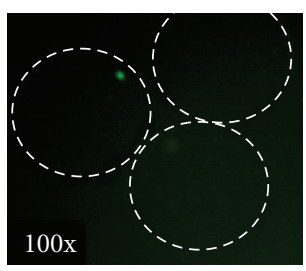

Day 15

(b)

FIgURE 8: Time-course profile of transgene expression of AP-PEG-A microencapsulated H9c2 cells transduced with Bac-MGFP under optimal transduction condition. The average fluorescein-expressed values (excitation $485 \mathrm{~nm}$, emission $535 \mathrm{~nm}$ ) were normalized to that of cells with $24 \mathrm{hpt} \mathrm{having} 6 \mathrm{~h}$ of viral incubation in presence of PBS (taken as 100\%) and are represented as normalized mean expression in percentage value (a). The data represent the mean of three different fields, and error bars represent standard error of the mean. Representative photographs of corresponding transduced microencapsulated cells were taken using fluorescence microscope under 100x magnification at different days after encapsulation (b). The white-dotted circles show the peripheral surface of the capsules.

nutrients to all the cells [11]. This leads to the need of a perfusion system through a core vessel to provide oxygen within the scaffold [47]. In comparison, the larger exposed surface area of the capsules allows easy diffusion of nutrients and metabolites in and out of the capsule encapsulating a high density of cells.

3.5. Mechanical and Osmotic Stability of the AP-PEG-A Microcapsules. To evaluate the mechanical and osmotic stability of the PEG-modified membrane, the cell-encapsulated capsules were subjected to rotational and osmotic stress as mentioned in Section 2. The AP-PEG-A microcapsules were able to withstand the combined mechanical and osmotic forces as evident in the graph of Figure 7(a), representing the percentage of cells still encapsulated. $75 \%$ of the cells remained encapsulated in AP-PEG-A microcapsules after $1 \mathrm{~h}$, which reduced marginally to only $71 \%$ after $2 \mathrm{~h}$. The observed stability can be because of the penetration of PEG into the alginate core of the capsule that gives an added stability to the capsule when exposed to stress conditions [48]. The reason for such high stability can also be attributed to the strong interpenetrating network formed by PEG on the capsular surface.

3.6. Immunoprotective Potential of the AP-PEG-A Microcapsules. The ability of the AP-PEG-A capsules to provide immunogenic protection to the encapsulated cells were studied by coculturing microencapsulated Bac-null transduced
H9c2 cells with lymphocytes derived from mouse origin for 8 days. It can be concluded from Figure 8(a) that the average viability of the AP-PEG-A encapsulated cells started to decrease significantly only from day $8(87 \%)$. That means that the capsules were able to withstand the external immune forces for at least 8 days, which is much longer and stronger than other commonly used delivery systems [22]. This is because it is important to have microcapsules with minimum surface charges to avoid foreign body reactions when transplanted [49]. The positively charged PLL binds with negatively charged alginate through electrostatic interaction which results in interfacial adsorption of PLL forming a thin layer of PLL on the alginate core. An improper coating can make the capsular surface charged. Hydrophilic, nonionic, and the inert nature of PEG make it an ideal candidate to neutralize the surface charge and hence increase the immunoprotective potential of the capsules by alleviating the chance of having surface protein adhesions $[19,50]$.

\subsection{Transgene Expression Profile of Baculovirus-Transduced} Cells Encapsulated in AP-PEG-A Microcapsules. In order to demonstrate the gene expression pattern of the APPEG-A microencapsulated transduced cells, H9c2 cells were Bac-MGFP transduced and right away encapsulated at a concentration of 2 million cells per $\mathrm{ml}$ of alginate to prepare the AP-PEG-A microcapsules. The encapsulated cardiomyoblasts were then cultured in stationary flasks in $10 \%$ DMEM medium supplemented with FBS and antibiotics. 
The relative fluorescence units of each well-containing 50 capsules resuspended in $200 \mu \mathrm{L}$ PBS were then measured on different time intervals using the Victor3 Multilabel Plate Counter (Perkin Elmer, USA). Figure 8 reveals that the transgene expression had a rapid expression pattern with the highest expression observed on day 1 , as is evident by the normalized gene expression data with time. It shows the highest expression (considered as 100\%) on day 1, which gradually diminished with days. The graph delineates that the GFP expression level remained high at $\sim 50 \%$ on day 7 but dropped to $\sim 15 \%$ on day 9 . This decrease in transgene expression is mainly because of the transient nature of cell expression mediated by baculovirus. This mechanism could be beneficial for cell-based gene therapy, where the cells will express the transgene temporarily and stop after the treatment period when its secretion will no longer be needed. The cells can be genetically modified with different therapeutic genes based on the mode of treatment. So far, bioengineered cardiomyocyte sheet grafts have been used to induce myocardial angiogenesis $[12,51]$. In fact, the microcapsules can also be supplemented with the cocktail of growth factors to promote neovascularization and better survival rate of transplanted cells in vivo $[52,53]$.

\section{Conclusion}

Our results demonstrate that baculovirus can be efficiently used to genetically modify murine cardiomyocytes under our optimized transduction protocol. This is particularly important as a gene delivery system because baculoviral proteins cannot interact with host cell proteins and nucleic acids, which can otherwise affect the host cell cycle and its viability. This makes this insect cell-originated viral vector a biologically safe and efficient vector for gene therapy applications in comparison to mammalian viral vectors. Our paper shows for the first time that the genetically modified cardiomyocyte cells can survive and even proliferate inside the microcapsules.

Cardiac cell transplantation is limited mainly due to poor graft viability [2]. Our recent findings on animal studies have demonstrated that microencapsulated cell delivery system can increase the transplanted cell retention capacity by four times in comparison to free cells when injected intramyocardially in a beating heart $[16,54,55]$. To further reduce the biological and mechanical loss of the transplanted cardiomyocytes in the harsh contractile myocardial environment, we modified the alginate microcapsules by incorporating PEG. This not only preserved the encapsulated cell viability and proliferation potential but also increased mechanical strength and immunoprotective potential. Baculovirus transduced AP-PEG-A microencapsulated cells showed a rapid expression of its transgene which persisted for at least two weeks. In summary, this study suggests that recombinant baculovirus-mediated genetically modified cardiomyocytes, expressing therapeutic proteins, encapsulated in AP-PEGA microcapsules hold immense potential in myocardial transplantation using direct intramyocardial route of administration. This system can be implemented in the future to transfer angiogenic transgene like VEGF through the microencapsulated genetically modified cardiomyocytes to reduce myocardial infarction and improve heart function, although further research is needed to be done in vivo to evaluate its potential for preclinical and clinical applications.

\section{Acknowledgments}

This work is supported by research grant (to D. ShumTim and S. Prakash) from Natural Sciences and Engineering Research Council (NSERC), Canada and Canadian Institutes of Health Research (CIHR) MOP \# 6430 grant to S. Prakash. A. Paul acknowledges the financial support from NSERC Alexander Graham Bell Canada Graduate Scholarship.

\section{References}

[1] A. K. Gehi, S. P. Pinney, and A. Gass, "Recent diagnostic and therapeutic innovations in heart failure management," Mount Sinai Journal of Medicine, vol. 72, no. 3, pp. 176-184, 2005.

[2] I. Kutschka, I. Y. Chen, T. Kofidis et al., "Collagen matrices enhance survival of transplanted cardiomyoblasts and contribute to functional improvement of ischemic rat hearts," Circulation, vol. 114, no. 1, pp. I167-I173, 2006.

[3] M. A. Laflamme and C. E. Murry, "Regenerating the heart," Nature Biotechnology, vol. 23, no. 7, pp. 845-856, 2005.

[4] T. C. McDevitt, K. A. Woodhouse, S. D. Hauschka, C. E. Murry, and P. S. Stayton, "Spatially organized layers of cardiomyocytes on biodegradable polyurethane films for myocardial repair," Journal of Biomedical Materials Research A, vol. 66, no. 3, pp. 586-595, 2003.

[5] O. Ishii, M. Shin, T. Sueda, and J. P. Vacanti, "In vitro tissue engineering of a cardiac graft using a degradable scaffold with an extracellular matrix-like topography," Journal of Thoracic and Cardiovascular Surgery, vol. 130, no. 5, pp. 1358-1363, 2005.

[6] X. Zong, H. Bien, C. Y. Chung et al., "Electrospun finetextured scaffolds for heart tissue constructs," Biomaterials, vol. 26, no. 26, pp. 5330-5338, 2005.

[7] A. Dar, M. Shachar, J. Leor, and S. Cohen, "Optimization of cardiac cell seeding and distribution in $3 \mathrm{D}$ porous alginate scaffolds," Biotechnology and Bioengineering, vol. 80, no. 3, pp. 305-312, 2002.

[8] M. J. Yost, C. F. Baicu, C. E. Stonerock et al., "A novel tubular scaffold for cardiovascular tissue engineering," Tissue Engineering, vol. 10, no. 1-2, pp. 273-284, 2004.

[9] R. K. Birla, G. H. Borschel, R. G. Dennis, and D. L. Brown, "Myocardial engineering in vivo: formation and characterization of contractile, vascularized three-dimensional cardiac tissue," Tissue Engineering, vol. 11, no. 5-6, pp. 803-813, 2005.

[10] M. Radisic, M. Euloth, L. Yang, R. Langer, L. E. Freed, and G. Vunjak-Novakovic, "High-density seeding of myocyte cells for cardiac tissue engineering," Biotechnology and Bioengineering, vol. 82, no. 4, pp. 403-414, 2003.

[11] M. Radisic, W. Deen, R. Langer, and G. Vunjak-Novakovic, "Mathematical model of oxygen distribution in engineered cardiac tissue with parallel channel array perfused with culture medium containing oxygen carriers," American Journal of Physiology, vol. 288, no. 3, pp. H1278-H1289, 2005.

[12] S. Sekiya, T. Shimizu, M. Yamato, A. Kikuchi, and T. Okano, "Bioengineered cardiac cell sheet grafts have intrinsic 
angiogenic potential," Biochemical and Biophysical Research Communications, vol. 341, no. 2, pp. 573-582, 2006.

[13] Q. P. Pham, U. Sharma, and A. G. Mikos, "Electrospinning of polymeric nanofibers for tissue engineering applications: a review," Tissue Engineering, vol. 12, no. 5, pp. 1197-1211, 2006.

[14] S. Dimmeler, A. M. Zeiher, and M. D. Schneider, "Unchain my heart: the scientific foundations of cardiac repair," Journal of Clinical Investigation, vol. 115, no. 3, pp. 572-583, 2005.

[15] K. Suzuki, B. Murtuza, J. R. Beauchamp et al., "Role of interleukin- $1 \beta$ in acute inflammation and graft death after cell transplantation to the heart," Circulation, vol. 110, no. 11, pp. II219-II224, 2004.

[16] C. J. Teng, J. Luo, R. C. J. Chiu, and D. Shum-Tim, "Massive mechanical loss of microspheres with direct intramyocardial injection in the beating heart: implications for cellular cardiomyoplasty," Journal of Thoracic and Cardiovascular Surgery, vol. 132, no. 3, pp. 628-632, 2006.

[17] S. Prakash and T. M. S. Chang, "Microencapsulated genetically engineered live E. coli DH5 cells administered orally to maintain normal plasma urea level in uremic rats," Nature Medicine, vol. 2, no. 8, pp. 883-887, 1996.

[18] T. M. S. Chang, "Semipermeable microcapsules," Science, vol. 146, no. 3643, pp. 524-525, 1964.

[19] A. Paul, D. Shum-Tim, and S. Prakash, "Investigation on PEG integrated alginate-chitosan microcapsules for myocardial therapy using marrow stem cells genetically modified by recombinant baculovirus," Cardiovascular Engineering and Technology, vol. 1, no. 2, pp. 154-164, 2010.

[20] S. Prakash and T. M. S. Chang, "Artificial cell microcapsules containing genetically engineered E. coli DH5 cells for invitro lowering of plasma potassium, phosphate, magnesium, sodium, chloride, uric acid, cholesterol, and creatinine: a preliminary report," Artificial Cells, Blood Substitutes, and Immobilization Biotechnology, vol. 27, no. 5-6, pp. 475-481, 1999.

[21] S. Prakash and J. Bhathena, "Live bacterial cells as orally delivered therapeutics," Expert Opinion on Biological Therapy, vol. 5, no. 10, pp. 1281-1301, 2005.

[22] O. Gåserød, A. Sannes, and G. Skjåk-Bræk, "Microcapsules of alginate-chitosan. II. A study of capsule stability and permeability," Biomaterials, vol. 20, no. 8, pp. 773-783, 1999.

[23] T. Haque, H. Chen, W. Ouyang et al., "In vitro study of alginate-chitosan microcapsules: an alternative to liver cell transplants for the treatment of liver failure," Biotechnology Letters, vol. 27, no. 5, pp. 317-322, 2005.

[24] A. M. Rokstad, S. Holtan, B. Strand et al., "Microencapsulation of cells producing therapeutic proteins: optimizing cell growth and secretion," Cell Transplantation, vol. 11, no. 4, pp. 313-324, 2002.

[25] G. Grassi, H. Köhn, B. Dapas et al., "Comparison between recombinant baculo- and adenoviral-vectors as transfer system in cardiovascular cells," Archives of Virology, vol. 151, no. 2, pp. 255-271, 2006.

[26] D. R. O’Reilly, L. K. Miller, and V. A. Lucknow, Baculovirus Expression Vector: A Laboratory Manual, W.H.Freeman, New York, NY, USA, 1992.

[27] S. T. Tjia, G. Meyer zu Altenschildesche, and W. Doerfler, "Autographa californica nuclear polyhedrosis virus (AcNPV) DNA does not persist in mass cultures of mammalian cells," Virology, vol. 125, no. 1, pp. 107-117, 1983.

[28] B. A. Jardin, Y. Zhao, M. Selvaraj et al., "Expression of SEAP (secreted alkaline phosphatase) by baculovirus mediated transduction of HEK 293 cells in a hollow fiber bioreactor system," Journal of Biotechnology, vol. 135, no. 3, pp. 272-280, 2008.

[29] A. Paul, B. A. Jardin, A. Kulamarva, M. Malhotra, C. B. Elias, and S. Prakash, "Recombinant baculovirus as a highly potent vector for gene therapy of human colorectal carcinoma: molecular cloning, expression, and in vitro characterization," Molecular Biotechnology, vol. 45, no. 2, pp. 129-139, 2010.

[30] M. Mirzaei, B. Jardin, C. B. Elias, and S. Prakash, "Expression and production of human interleukin-7 in insect cells using Baculovirus Expression Vector System (BEVS)," Applied Biochemistry and Biotechnology, vol. 151, no. 1, pp. 93-103, 2008.

[31] A. Kulamarva, J. Bhathena, M. Malhotra et al., "In vitro cytotoxicity of functionalized single walled carbon nanotubes for targeted gene delivery applications," Nanotoxicology, vol. 2, no. 4, pp. 184-188, 2008.

[32] H. Chen, W. Ouyang, B. Lawuyi, and S. Prakash, "Genipin cross-linked alginate-chitosan microcapsules: membrane characterization and optimization of cross-linking reaction," Biomacromolecules, vol. 7, no. 7, pp. 2091-2098, 2006.

[33] H. Chen, W. Ouyang, M. Jones et al., "Preparation and characterization of novel polymeric microcapsules for live cell encapsulation and therapy," Cell Biochemistry and Biophysics, vol. 47, no. 1, pp. 159-167, 2007.

[34] T. Maguire, E. Novik, R. Schloss, and M. Yarmush, "AlginatePLL microencapsulation: effect on the differentiation of embryonic stem cells into hepatocytes," Biotechnology and Bioengineering, vol. 93, no. 3, pp. 581-591, 2006.

[35] T. Haque, H. Chen, W. Ouyang et al., "Investigation of a new microcapsule membrane combining alginate, chitosan, polyethylene glycol and poly-L-lysine for cell transplantation applications," International Journal of Artificial Organs, vol. 28, no. 6, pp. 631-637, 2005.

[36] P. A. Kitts and G. Green, "An immunological assay for determination of baculovirus titers in 48 hours," Analytical Biochemistry, vol. 268, no. 2, pp. 173-178, 1999.

[37] V. Janakiraman, W. F. Forrest, and S. Seshagiri, "Estimation of baculovirus titer based on viable cell size," Nature Protocols, vol. 1, no. 5, pp. 2271-2276, 2006.

[38] H. R. Lo and Y. C. Chao, "Rapid titer determination of baculovirus by quantitative real-time polymerase chain reaction," Biotechnology Progress, vol. 20, no. 1, pp. 354-360, 2004.

[39] T. B. Morrison, Y. Ma, J. H. Weis, and J. J. Weis, "Rapid and sensitive quantification of Borrelia burgdorferi-infected mouse tissues by continuous fluorescent monitoring of PCR," Journal of Clinical Microbiology, vol. 37, no. 4, pp. 987-992, 1999.

[40] C. Hofmann and M. Strauss, "Baculovirus-mediated gene transfer in the presence of human serum or blood facilitated by inhibition of the complement system," Gene Therapy, vol. 5, no. 4, pp. 531-536, 1998.

[41] YI. Yang, S. L. Lo, J. Yang et al., "Polyethylenimine coating to produce serum-resistant baculoviral vectors for in vivo gene delivery," Biomaterials, vol. 30, no. 29, pp. 5767-5774, 2009.

[42] Y. K. Kim, J. Y. Choi, H. L. Jiang et al., "Hybrid of baculovirus and galactosylated PEI for efficient gene carrier," Virology, vol. 387, no. 1, pp. 89-97, 2009.

[43] K. Niwano, M. Arai, N. Koitabashi et al., "Lentiviral vectormediated SERCA2 gene transfer protects against heart failure and left ventricular remodeling after myocardial Infarction in rats," Molecular Therapy, vol. 16, no. 6, pp. 1026-1032, 2008.

[44] K. Takahashi, Y. Ito, M. Morikawa et al., "Adenoviral-delivered angiopoietin-1 reduces the infarction and attenuates the progression of cardiac dysfunction in the rat model of acute 
myocardial infarction," Molecular Therapy, vol. 8, no. 4, pp. 584-592, 2003.

[45] M. Ferrarini, N. Arsic, F. A. Recchia et al., "Adeno-associated virus-mediated transduction of VEGF165 improves cardiac tissue viability and functional recovery after permanent coronary occlusion in conscious dogs," Circulation Research, vol. 98, no. 7, pp. 954-961, 2006.

[46] L. Pieroni, D. Maione, and N. La Monica, "In vivo gene transfer in mouse skeletal muscle mediated by baculovirus vectors," Human Gene Therapy, vol. 12, no. 8, pp. 871-881, 2001.

[47] T. Kofidis, A. Lenz, J. Boublik et al., "Pulsatile perfusion and cardiomyocyte viability in a solid three-dimensional matrix," Biomaterials, vol. 24, no. 27, pp. 5009-5014, 2003.

[48] D. B. Seifert and J. A. Phillips, "Porous alginate-poly(ethylene glycol)entrapment system for the cultivation of mammalian cells," Biotechnology Progress, vol. 13, no. 5, pp. 569-576, 1997.

[49] G. Orive, R. M. Hernández, A. Rodríguez Gascón et al., "History, challenges and perspectives of cell microencapsulation," Trends in Biotechnology, vol. 22, no. 2, pp. 87-92, 2004.

[50] J. Zimmermann, K. Bittner, B. Stark, and R. Mülhaupt, "Novel hydrogels as supports for in vitro cell growth: poly(ethylene glycol)- and gelatine-based (meth)acrylamidopeptide macromonomers," Biomaterials, vol. 23, no. 10, pp. 21272134, 2002.

[51] Y. C. Huang, L. Khait, and R. K. Birla, "Contractile threedimensional bioengineered heart muscle for myocardial regeneration," Journal of Biomedical Materials Research A, vol. 80, no. 3, pp. 719-731, 2007.

[52] M. Fujita, Y. Kinoshita, E. Sato et al., "Proliferation and differentiation of rat bone marrow stromal cells on poly(glycolic acid)-collagen sponge," Tissue Engineering, vol. 11, no. 9-10, pp. 1346-1355, 2005.

[53] W. H. Zimmermann, M. Didié, G. H. Wasmeier et al., "Cardiac grafting of engineered heart tissue in syngenic rats," Circulation, vol. 106, no. 13, pp. I151-I157, 2002.

[54] A. Paul, Y. Ge, S. Prakash, and D. Shum-Tim, "Microencapsulated stem cells for tissue repairing: implications in cell-based myocardial therapy," Regenerative Medicine, vol. 4, no. 5, pp. 733-745, 2009.

[55] A. H. Al Kindi, J. F. Asenjo, Y. Ge et al., "Microencapsulation to reduce mechanical loss of microspheres: implications in myocardial cell therapy," European Journal of Cardio-Thoracic Surgery. In press. 

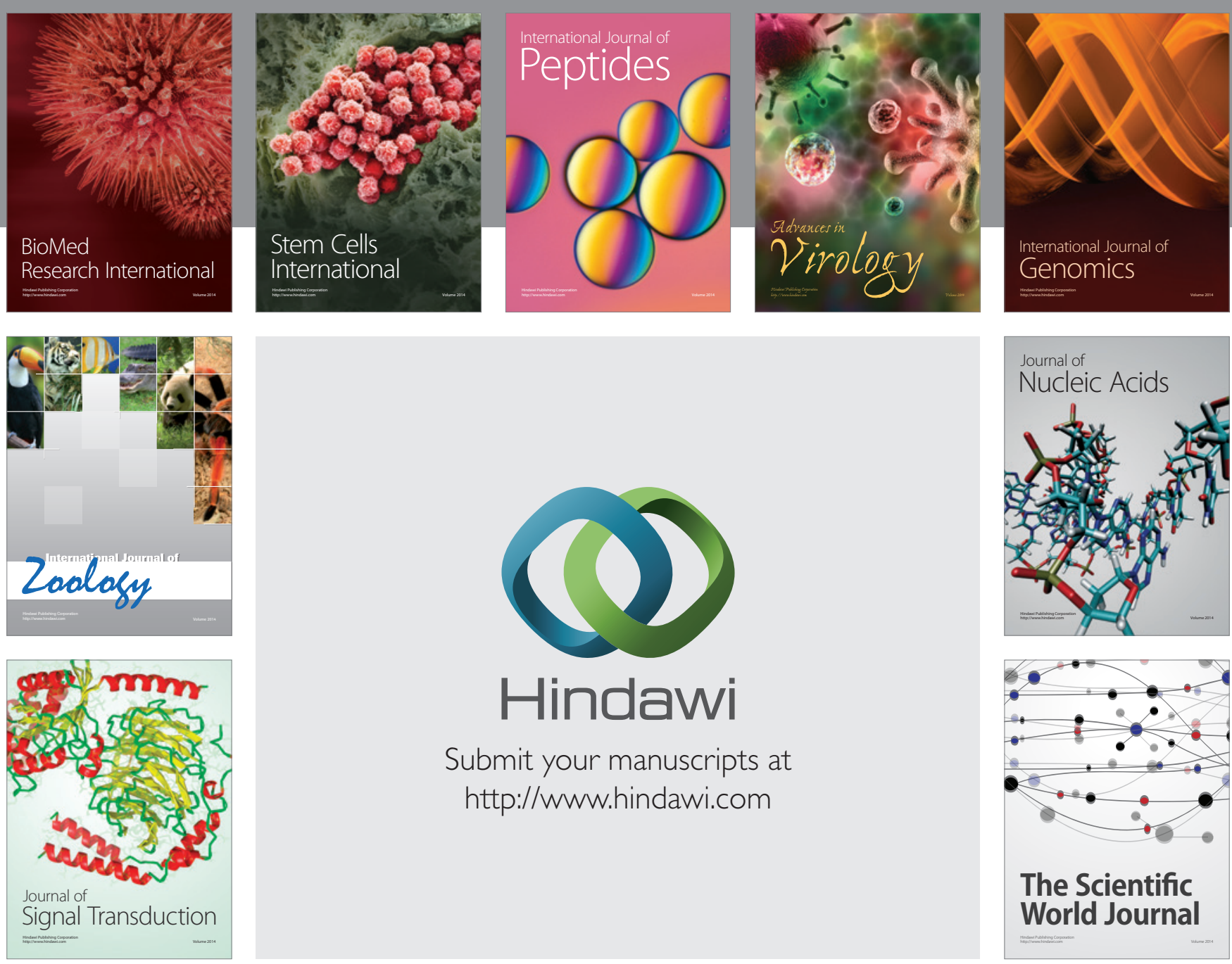

Submit your manuscripts at

http://www.hindawi.com
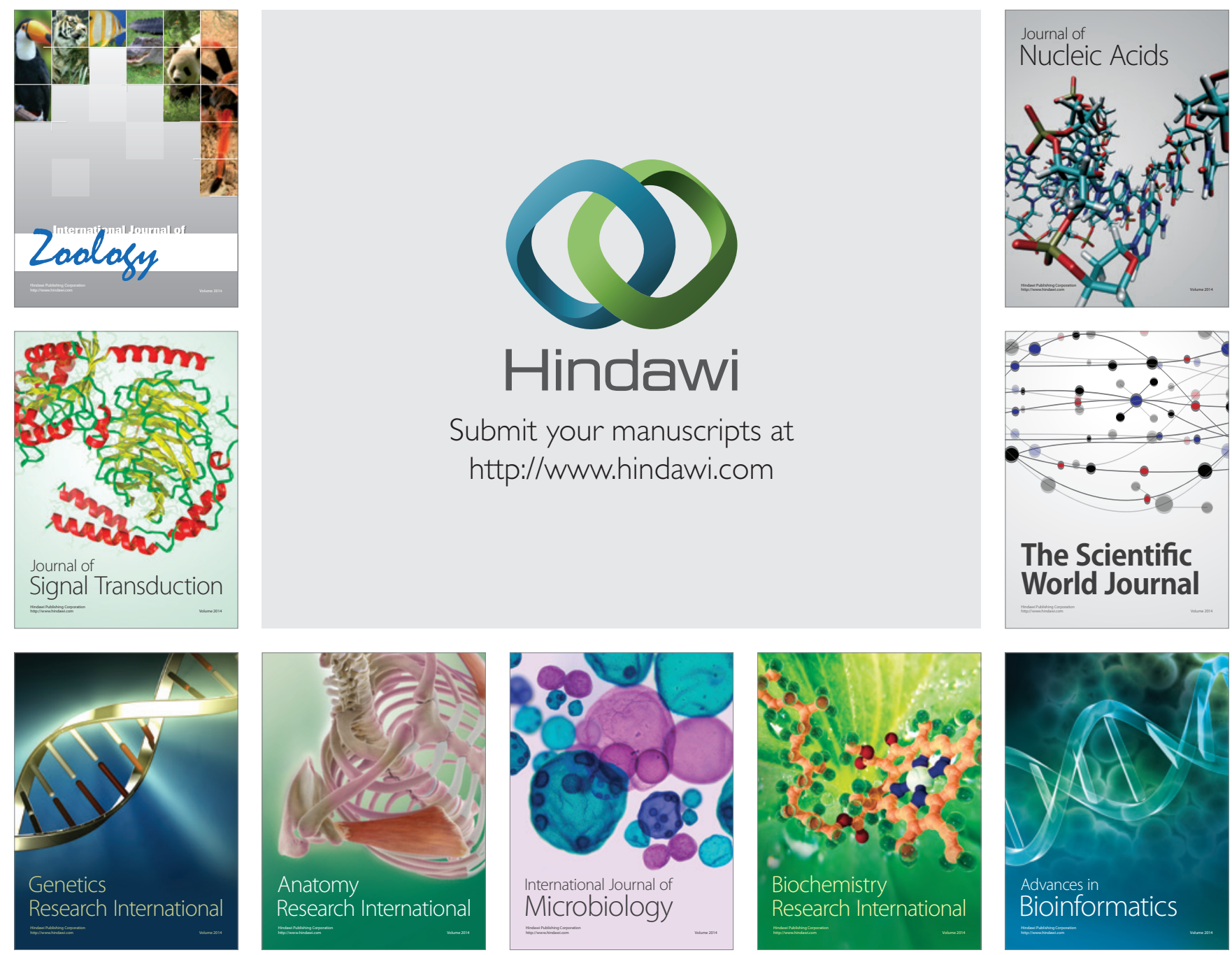

The Scientific World Journal
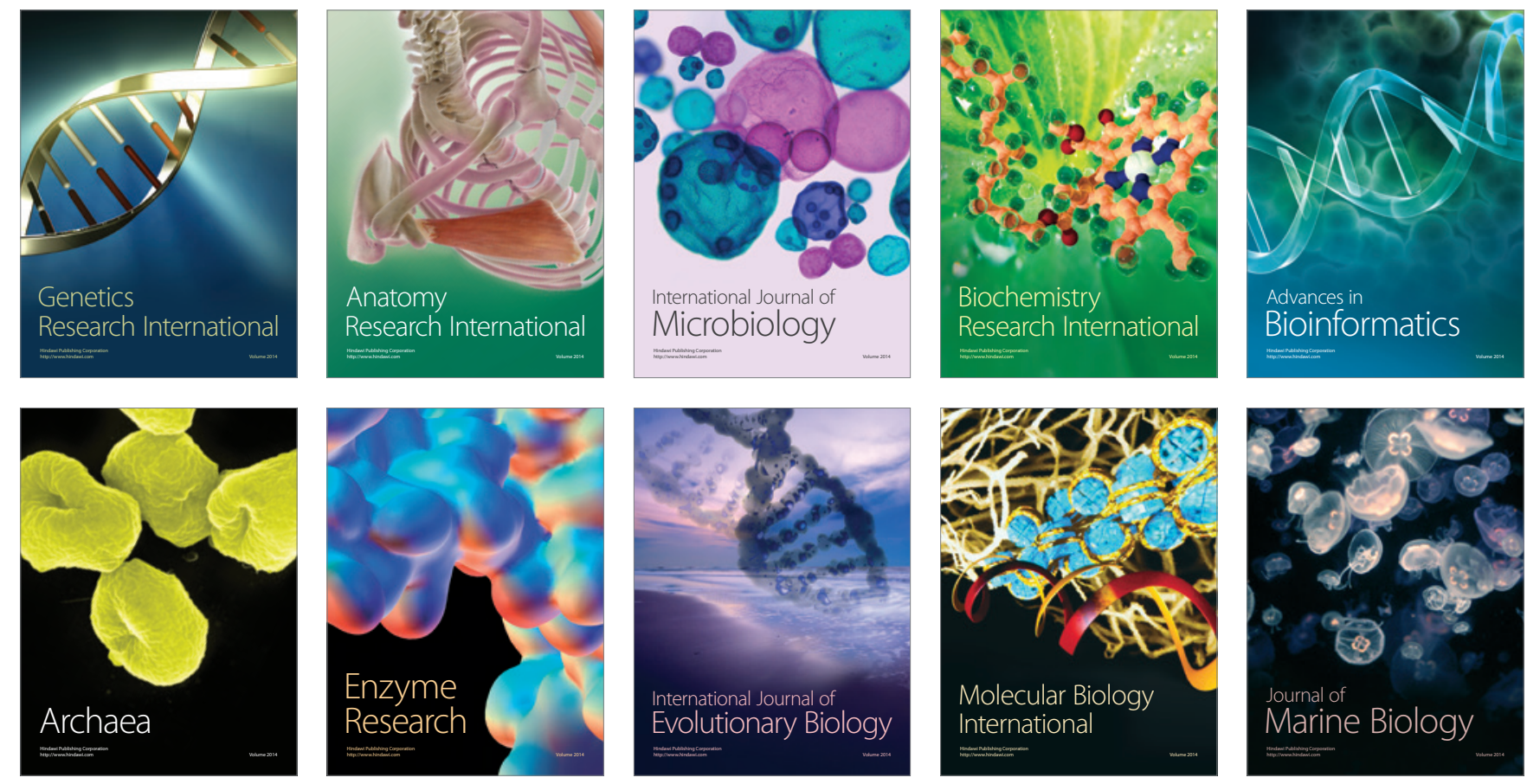